\title{
Reproductive Strategy of Aegiceras corniculatum L. (Blanco.) - A Mangrove Species, in MNP\&S, Gujarat, India
}

\author{
Richa Pandey ${ }^{1} \&$ C. N. Pandey ${ }^{1}$ \\ ${ }^{1}$ Gujarat Forest Department, Gujarat, India \\ Correspondence: Richa Pandey, Gujarat Forest Department, Gujarat, India. E-mail: richa81181@yahoo.co.in
}

Received: March 13, 2013 Accepted: October 6, 2013 Online Published: October 18, 2013

doi:10.5539/jps.v3n1p35

URL: http://dx.doi.org/10.5539/jps.v3n1p35

\begin{abstract}
Mangroves occur in the tropical and subtropical inter-tidal regions of the world. Owing to their locations, they are expected to have a reproductive strategy which can facilitate generalized pollination. The present work has examined the floral biology, breeding system, pollinator resource and their efficiency, and the reproductive strategy of Aegiceras corniculatum L. (Blanco) at three islands (three populations) in Marine National Park and Sanstuary (MNP\&S), Gulf of Kachchh, Gujarat, India. The temporal relations in the floral processes such as anther dehiscence, stigma receptivity and nectar secretion were studied and the results were juxtaposed to have comprehensive view. The floral life is very long ( 21 days) and the pace of floral transformation varies with the floral process. Significant diurnal variations in the stigma receptivity and nectar secretions influence the pollinators' availability during different periods of the day. All the three breeding systems are present indicating occurrence of autogamy. However, strong protandry reduces its possibility to a significant level. Further, the asynchrony in the flowering processes at inflorescence level and the foraging behavior of pollinators increase the possibility of geitonogamy. The reproductive strategy of the plant is inclined towards cross pollination with keeping some possibility of self-pollination.
\end{abstract}

Keywords: mangrove, Aegiceras corniculatum, floral biology, pollination biology, stigma receptivity, nectar, pollinator, India

\section{Introduction}

\subsection{Floral Biology- A Brief History}

Though floral biology has attracted biologists since eighteenth century, the most fundamental and comprehensive observations were made by Sprengel (1793) who had successfully explained floral biology of 461 angiosperms (with 1117 illustrations) in terms of floral transformations, functions, fitness, guides, rewards and its association with pollinator resource, determining the type and efficiency of breeding systems. Contrarily, Kölreuter (1761-1766), was of the view that the beauty of flowers had nothing to do with pollination. Willdenow (1802) had supported Sprengel's view while many contemporary workers such as Goethe (1790), Meyer (1953) and Henschel (1820) rejected it and, therefore, it remained in oblivion for decades. Darwin (1888) has rebound Sprengle's philosophy. Thereafter, evolution of plant breeding systems, their efficiency and the regulatory factors have gain enormous attention of biologists (Vogel, 1996; Richards, 1997). However, much of such works were confined to territorial species and very few addressed intertidal species such as mangroves.

\subsection{Biology of Mangroves}

Mangroves represent the intertidal tropical and sub-tropical communities and the plant component thereof (Tomlinson, 1986). The long distant dispersal of their propagules, largely through water, play important role in their geographical distribution and high inter-population genetic diversity (Geng et al., 2008). Owing to their unique habitat and physiological characters, majority of works pertained to their floristic diversity (Tomlinson, 1986; Rajgopalan, 1987; Banerjee, Shashtri, \& Nayar, 1989; Banerjee, Rao, Shashtri \& Gosh, 2002; Debnath, 2004; C. N. Pandey \& R. Pandey, 2009), ecology (Odum, McIvor, \& Smithh III, 1982; Tomlinson, 1986; Kathiresan \& Bingham, 2001; Ellison, 2008; Morrisey et al., 2010), seed dispersal (Yamashiro, 1961; Steinke, 1986; Clark, 1993; McGuinness, 1997; Stocken et al., 2013) and genetics (Lakshmi, Rajalakshmi, Parani, Anuratha, \& Parida 1997; Maguire, Saenger, Baverstock, \& Henry, 2000; Lakshmi, Parani, \& Parida, 2002; Melville \& Burchett, 2002; Kado et al., 2004; Nagrajan, Pandiarajan, Krishnmoorthy, \& Sophia, 2008; Homer, 
2009). Much less studies have been carried out on the floral biology and reproductive ecology of mangroves (Tomlinson, Primack, \& Bunt, 1979; Duke, Bunt \& Williams, 1884; Juncosa \& Tomlinson, 1987; Steinke, 1988; Aluri, 1990; Coupland, Paling, \& McGuinness, 2005; Ghosh, Gupta, Maity, \& Das, 2008; Almazol \& Cervancia, 2013).

\subsection{Reproductive Phenology of Mangroves}

Spatial and temporal variations in the reproductive phenology of mangroves are reported (Duke, 2006). K. candel has been reported to take about nine months to complete the reproductive cycle with distinct flowering and fruiting peaks (Kamruzzaman, Sharma, \& Hagihara, 2013). Day length, wind speed, mean air temperature and monthly rainfall had shown strong correlation with vegetative and reproductive cycles of $K$. candel (Kamruzzaman et al., 2013). Further, salinity and air vapor pressure deficit have been found to trigger flowering in Rhizophora mangle, Laguncularia racemosa and Avicennia germinans in the neotropical region (Sánchez-Núñez \& Mancera-Pineda, 2011). The reproductive phase continues throughout the year in Aegiceras corniculatum, Ceriops tagal and Rhizophora mucronata, at western coast of India however, their flowering and fruiting show distinct temporal and spatial variations (C. N. Pandey \& R. Pandey, 2010a; C. N. Pandey, R. Pandey, \& Jain, 2010b; R. Pandey \& C. N. Pandey, 2013a).

\subsection{Floral Biology an Pollination in Mangroves}

Reproductive biology of many mangals have been examined (Elliot, Edward, \& Godfrey, 1996). Some mangroves species such as Avicennia (Clarke \& Myerscough, 1991; Solomon Raju, Rao, Kumar, \& Mohan, 2012; Nadia, Menezes \& Machado, 2013), Bruguiera (Davey, 1975; Noske, 1993; Nagrajan et al., 2008; Kamruzzaman et al., 2013), Ceriops (Solomon Raju et al., 2006; Nagrajan et al., 2008; Solomon Raju, \& Karyamserry, 2008, Pandey \& Pandey, 2010a), Rhizophpra (Nagrajan et al., 2008; C. N. Pandey \& R. Pandey, 2010a; Ghosh \& Chakraborti, 2011; Seetharaman \& Kathiresan, 2011), Laguncularia (Landry \& Rathcke, 2007), Kandelia (Sun, Wong, \& Lee, 1998), Aegiceras (Aluri, 1990; Clark, 1995; Ge \& Sun, 1999; Lieu \& Hong, 2004; Pandit \& Choudhury, 2001; R. Pandey \& C. N. Pandey, 2013a), Scyphiphora hydrophyllacea (Almazol \& Cervancia, 2013), Xylocarpus granatm (Almazol \& Cervancia, 2013) and Sonneretia (Pandit \& Choudhury, 2001) have been examined for diferrent aspects of reproductiv biology such as population structure, floral biology, breeding systems, pollination etc.

\subsection{Pollination Biology of Mangroves}

Pollination and subsequent reproductive success of plants are subject many factors viz. availability of floral rewards, effective pollinator resource etc. Owing to their remote locations and less availability of pollinator resources, mangroves are considered to have generalized pollination system (Tomlinson, 1986) in which plant utilizes vast spectrum of pollinator resource (ants, butterflies, bees, moths, bats, birds etc.) for its pollination and is generally facilitated by their gregarious flowering to enhance visual attraction (Willson, 1983; Wyatt, 1983; Harder \& Barrett, 1996; C. N. Pandey \& R. Pandey, 2010a; R. Pandey \& C. N. Pandey, 2013b). However, many times it leads to high inbreeding, the cause of low intra-population genetic diversity (Geng et al., 2008). Pollen grains and nectar are considered the most effective rewards for (floral visitors) pollinators. Azuma, Toyota, Asakawa, Takaso and Tobe, (2002) have examine floral scent of eight mangrove species and concluded that the chemical composition of floral scents can be correlated with floral morphology and pollinators. Variations in the pollinator availability and their efficiency have been reported for three mangrove species in the neotropical (Sánchez-Núñez \& Mancera-Pineda, 2012) and tropical regions (C. N. Pandey \& R. Pandey, 2010a; R. Pandey \& C. N. Pandey, 2013b).

\subsection{A. corniculatum - The Selected Species}

The genus Aegiceras initially placed in Myrsinaceae, however, latter it was kept in the family Aegiceraceae (Tomlinson, 1986). Two other genera of this family Ardisia and Myrsine are reported from mangrove habitats (Tomlinson, 1986; Debnath, 2004; Naskar, 2004). The genus Aegiceras is represented by two species i.e. $A$. corniculatum Blanco and A. floridum (Tomlinson, 1986). A. corniculatum is an evergreen tree or shrub, distributed over Ceylon, South China, Hong Kong, Malaysia, Philippines, New Guinea and tropical Australia (Tomlinson, 1986). In India, A. corniculatum is distributed on the east coast, the west coast and in the islands of Andaman and Nicobar (Rajgopalan, 1987; Banerjee et al., 1989; Debnath, 2004; Naskar, 2004). In the state of Gujarat (located on the west coast of India), it is reported from mangrove forests of the Marine National Park and Sanstuary, Gulf of Kachchh, Jamnagar and from South Gujarat regions (GEER, 2000; C. N. Pandey \& R. Pandey, 2009; C. N. Pandey \& R. Pandey, 2010a).

Comprehensive understanding about the reproductive biology and pollination ecology is the pre-requisite for in 
situ conservation of any plant species. The floral biology of this species has been examined in many mangrove ecosystems of the world (Clark, 1995; Ge \& Sun, 1999; Lieu \& Hong, 2004) including India (Aluri, 1990; Pandit \& Choudhury, 2001; R. Pandey \& C. N. Pandey, 2013a). However, it has not been studied on the west coast of India, specifically in Gujarat. In spite of gregarious flowering, the seed setting and natural recruitment of this species are very low in the mangrove forests of Marine National Park and Sanctuary, Gujarat. Floral biology and availability of efficient pollinators play very important role in reproductive success of any species. It also influences the reproductive strategy of the species; however, these aspects have not been studied for this region. In order to fill this information gap, the present work has examined the floral biology, pollinator efficiency of Aegiceras corniculatum L. (Blanco), and attempted to outline its reproductive strategy in Marine National Park and Sanctuary, Gulf of Kachchh (GOK), Gujarat, India.

\section{Materials and Methods}

\subsection{Study Period and Study Area}

The study was carried out during March 2007 to May 2009 at the three islands i.e. Pirotan, Patthapir and Sanada of Marine National Park, located at the Southern part of Gulf of Kachchh, Gujarat, India. Pirotan is located between $22^{\circ} 35^{\prime} 849^{\prime \prime}$ North and 69 $57^{\prime} 486^{\prime \prime}$ East. Patthapir is located between $22^{\circ} 31^{\prime} 838^{\prime \prime}$ North and 69 $56^{\prime} 187^{\prime \prime}$ East. Sanada is located between $22^{\circ} 34^{\prime} 084^{\prime \prime}$ North and 69 $57^{\prime} 374^{\prime \prime}$ East. In addition to Aegiceras corniculatum, three more mangrove species- Ceriops tagal, Avicenna marina and Rhizophora mucronata - are found at these islands. Among mangrove associates, Salvadora persica L. Salicornia brachiata Roxb., Suaeda nudiflora Roxb., Suaeda monoica Forssk. Ex. Gmel., Cyperus rotundus L. subsp. Rotundus and Ipomoea pes-caprae (L.) R. Brown, etc. are most common. Human presence (except for ecotourism and management) is contained due to being located in Marine National Park. Further, soil is predominantly clayey and the tidal amplitude is high in the area which averages around 5-6 meters leading to partial or complete submergence of mangroves. Being in tropical region, three definite seasons prevail here (Summer: March to mid June, Rains: mid June to September, winter: October to February).

The floral biology has been studied in terms of floral transformations, floral processes (viz. anthesis, anther dehiscence, stigma receptivity, nectar secretion). Further, foraging behavior and pollen load on the body of floral visitors were studied for their pollination efficiency. For this, the present work has examined the major pollinators of A. corniculatum which were reported by Pandey and Pandey (2013b) for the same region (Table 3 ).

\subsection{Floral Transformations}

A total of 52 buds of St-1 (Table 1) were marked and observed daily at regular intervals ( $8.00 \mathrm{hrs}, 12.00 \mathrm{hrs}$ and $17.00 \mathrm{hrs}$ ) till they attained the maturity of St-10. During each observation, the floral stage, ongoing floral process and the morphological characters were noted.

Table 1. Morphological details of ten floral states of A. corniculatum

\begin{tabular}{ll}
\hline Floral stages & Morphological details \\
\hline St-1 & Matured bud without loose petals \\
St-2 & Separation of petals on their lateral margin/s \\
St-3 & Freshly opened flower having anthers without any slit \\
St-4 & Flower with bright white petals, anther/s having slits \\
St-5 & Flower with bright white petals, dried anther/s \\
St-6 & Flower with petals turned off-white, anther lobes brown and twisted \\
St-7 & Flower in which at least one anther shed off (senescence of anthers started) \\
St-8 & Flower without petals and anther (petal and anther senescence completed), style bright white \\
St-9 & Flower with only gynoecium, style turned light pink \\
St-10 & Fruit/Flower with only gynoecium present, style turned prominently pink \\
\hline
\end{tabular}

\subsection{Stigma Receptivity}

The stigma receptivity was examined by conducting five experiments: 
- in vitro examination of the stigma receptivity

- $\quad$ in vivo examination of the stigma receptivity

- $\quad$ pollination success of different floral stages

- diurnal variation in the stigma receptivity

- $\quad$ type of stigma (wet or dry)

\subsubsection{In Vitro Examination of Stigma Receptivity}

A total of 1000 floral samples (100 of each floral stage) were examined as per Dafni, (1997) and Dafni and Maues (1998). It works on the principal that the receptive stigma releases $\mathrm{CO}_{2}$ when it comes in contact with $\mathrm{H}_{2} \mathrm{O}_{2}$. Further, the degree of receptivity of each floral stage with receptive stigma was examined in terms of number of bubbles of $\mathrm{CO}_{2}$ it released when it comes in contact with $\mathrm{H}_{2} \mathrm{O}_{2}$ (Table 2).

Table 2. Degree of receptivity of stigma of different floral stages

\begin{tabular}{lll}
\hline Degree of Receptivity & No. of bubbles release & Category allotted \\
\hline Maximum & More than 5 & A \\
Moderate & $<2,5>$ & B \\
Minimum & $<2$ & $\mathrm{C}$ \\
Absent & 0 & $\mathrm{O}$ \\
\hline
\end{tabular}

For eliminating the subjectivity and ambiguity about the degree to which the categories $\mathrm{A}$, $\mathrm{B}$ and $\mathrm{C}$ were different from category $\mathrm{O}$, 't test' was conducted treating the Category $\mathrm{O}$ as the "control". It has been applied to three pairs of data viz. O-C, O-B and O-A. For the purpose of the t test, the following Null hypothesis was adopted each time.

$H_{0}$ : The category under examination (category $\mathrm{C}, \mathrm{B}$ or $\mathrm{A}$ ) is different from the Category $\mathrm{O}$

$H_{l}$ : The category under examination (category $\mathrm{C}, \mathrm{B}$ or $\mathrm{A}$ ) is not different from the Category $\mathrm{O}$

Of the three categories (A, B and C), those which were found statistically not different from category $\mathrm{O}$ were clubbed together as single group - Group N (floral stages with significantly non-receptive stigma). Those categories which were found significantly different from group $\mathrm{O}$ were clubbed together and treated as Group $\mathrm{R}$ (floral stages with significantly receptive stigma).

\subsubsection{In Vivo Examination of Stigma Receptivity}

The stigmatic surfaces of different floral stages were examined for the number of non-germinated pollen grains and germinated pollen grains as per Johansen (1940). A total of 200 samples (20 of each floral stage -Table 1) were examined. The observed numbers of pollen grain on the stigma of different floral stages were categorized into three groups as follows.

Category $\mathrm{X}$ : Pollen grain without enlarged germ pores or pollen tubes (non-germinated pollen grains)

Category Y: Pollen grain with enlarged germ pores but without pollen tube

Category Z: Pollen grain with pollen tube (germinated pollen grains)

The percent distribution of pollen grains belonging to category $\mathrm{Y}$ and $\mathrm{Z}$ have been juxtaposed against the percent distribution significant stigma receptivity for in vivo examination of different floral stages.

\subsubsection{Pollination Success}

The ratio of the number of pollen tube formation in the style to the total pollen grain load on the stigma (Alonoso \& Herrera, 2008) was studied as per the Equation (1). A total of 120 samples, spread over six floral stages (St-4, St-5, St-6, St-7, St-8 and St-9) were examined.

$$
\text { Pollination Success }=\frac{\text { No. of Pollen tubes formation in the style }}{\text { Total pollen grain load on the stigma }}
$$

2.3.4 Diurnal Variation in the Stigma Receptivity

The in vitro experiment of stigma receptivity was conducted during three time zones T1 (8:00 to12:00 hrs), T2 
(from 12:00 to16:00 hrs) and T3 (from 16:00 to 19:00 hrs). This experiment was conducted on four floral stages viz. St-6, St-7, St-8 and St-9. A total of 300 samples (25 floral specimens of each selected floral stage) examined in each of the three time zones for diurnal variation, if any.

\subsubsection{Type of Stigma}

The stigma of all the ten floral stages were collected, preserved in $70 \%$ alcohol and examined under scanning electron microscope for stigmatic exudates, if any.

\subsection{Nectar Secretion}

Under this section, following experiments were conducted:

- $\quad$ structure and location of floral nectaries

- $\quad$ availability of nectar in different floral stages

- diurnal variation in nectar availability

- chemical composition of nectar

\subsubsection{Structure and Location of Floral Nectaries}

The floral specimens were collected and processed (Johansen, 1940) for light microscopy. Some samples were preserved in $70 \%$ alcohol and observed under scanning electron microscope.

\subsubsection{Availability of Nectar in Different Floral Stages}

This experiment did not examined nectar production per flower per day, as the flowers were not bagged to avoid nectar collection by foragers. In fact, it attempted to examine nectar availability during different periods of the day. The presence of nectar was examined by putting a capillary tube at the source of nectar and holding it for 10 minutes and subsequently the volume of nectar was calculated. For each specimen, separate capillary tubes were taken. Further, each individual examined for nectar secretion was different. Since the senescence of petals and stamens takes place during St-8 (Table 1), nectar availability stops from St-8 onwards. Hence, the floral stages prior to St-8 (viz. St-1 to St-7) were examined for nectar secretion.

\subsubsection{Diurnal Variation in Nectar Secretion}

A total of 70 floral specimens (10 specimens of each floral stage St-1 to St-7) were examined during each time zone (T1, T2 and T3). Hence, 210 floral samples were examined.

\subsubsection{Chemical Composition of Nectar}

Thin Layer Chromatography (TLC) method was used to examine the sugar and amino acid components of nectar.

\subsection{Floral Morphometry}

It aimed to examine the physical separation between stigma and anther and also the rate of growth of gynoecium and androecium. The buds and flowers of four floral stages i.e. St-1, St-3, St-4 and St-8 were selected and a total of 120 samples (30 for each stage) were examined. The measurements were taken using a dissecting microscope and the measuring equipment or scale which could read up to 1/10th of the millimeter. Thus, the least count for linear measurements was $0.1 \mathrm{~mm}$. Further, the lengths of anther filament, anther lobs, ovary and style were measured. In addition the width of anther los were also taken.

\subsection{Pollination Biology}

Pandey and Pandey (2013b)* have identified major floral visitors of $A$. corniculatum and examined their spatial and temporal major floral visitors in GOK. The present study has taken it further and examined:

- Foraging behavior of major floral visitors

- Pollination efficiency of major floral visitors

- Major floral visitors : pollinators or non pollinators?

\subsubsection{Foraging Pattern of Major Floral Visitors}

A total of 21 species of floral visitors were observed for their foraging pattern in terms of their movement across the inflorescences, average foraging duration, physical contact of their body parts with the reproductive parts of flower (stigma/anther), foraging location/s (nectar/anther), associated floral visitors (if any). In the case of diurnal floral visitors, direct observations have been made. However, in the case of nocturnal floral visitors, video documentation has been carried out. 
Table 3. Details of observations made about foraging pattern of major floral visitors*

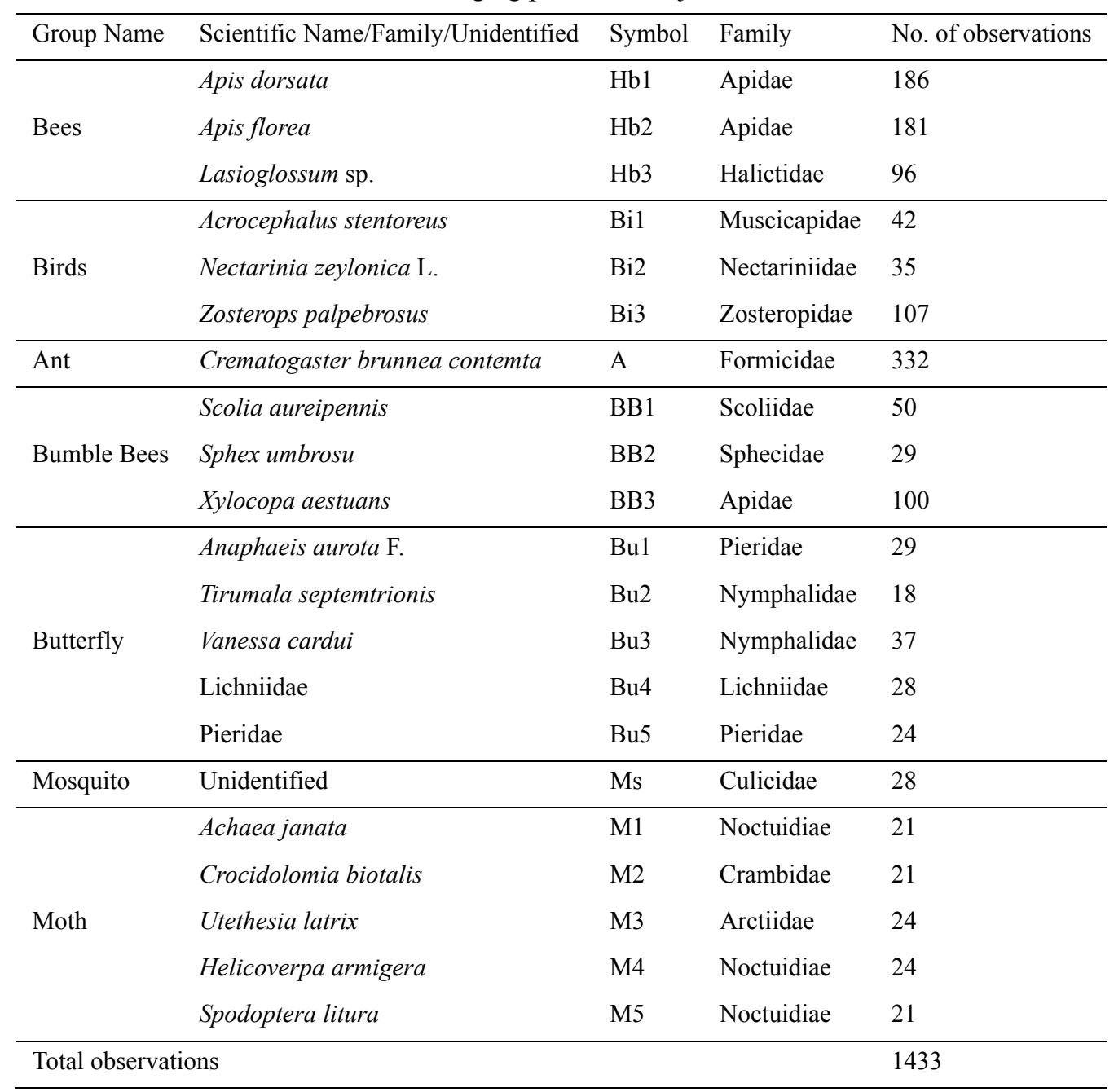

\subsubsection{Efficiency of Major Floral Visitor/Pollinators}

The major floral visitors were examined for the pollen grain/s of A. corniculatum on their body. The pollen grains of other existing flora were also collected to cross referred and ensure whether the pollen grains on the body of the floral visitors belonged to A. corniculatum or not. The floral visitors observed with pollen grain/s of A. corniculatum on their body were categorized at pollinators. The pollinators were further categorized as most efficient, moderately efficient or least efficient based on the pollen grain load on their body (Table 4).

Table 4. Categorization of pollinators based upon the pollen grain on their body

\begin{tabular}{ll}
\hline Category & Average pollen grain load on body \\
\hline Most efficient & $>50$ pollen grains \\
Moderately efficient & $21-50$ pollen grains \\
Least efficient & $01-20$ pollen grains \\
\hline
\end{tabular}

The pollen load on the body of butterflies, moths and birds could not be examined. In such cases, if their foraging behaviour suggest them as pollinator, have been treated as potential pollinators.

\subsection{Breeding Systems}

For autogamy, matured buds (St-1) were bagged individually in butter paper bags. A second set (Table 5) of matured buds (St-1) were emasculated and subsequently hand pollinated by the pollen grains of different flowers 
of the same plant (geitonogamy) and bagged with butter paper bags. For examined the occurrence of xenogamy, a third set of matured buds (Table 5) were emasculated and pollinated by pollen grain of different flowers of different plant and bagged with butter paper bags. Observations were taken fortnightly till the survived buds achieve fertilization successes indicated by morphological characters (Table 5).

Table 5. Details of breeding experiments

\begin{tabular}{lllll}
\hline $\begin{array}{l}\text { Breeding } \\
\text { mechanism }\end{array}$ & $\begin{array}{l}\text { No. of } \\
\text { samples }\end{array}$ & $\begin{array}{l}\text { Frequency } \\
\text { observation }\end{array}$ & of $\begin{array}{l}\text { Morphological character indicating } \\
\text { fertilization success }\end{array}$ \\
\hline Autogamy & 70 & & $\begin{array}{l}\text { Senescence of petals, anthers and dark } \\
\text { pinkish coloration of the style }\end{array}$ \\
Geitonogamy & 371 & Fortnight & \\
Xenogamy & 225 & & \\
\hline
\end{tabular}

\subsection{Reproductive Strategy}

This has been outlined based on the findings of sub sections $(2.2,2.3,2.4,2.5,2.6$ and 2.7).

\section{Results}

\subsection{Floral Transformations}

A matured bud of $A$. corniculatum takes $525 \mathrm{hrs}$ (about 21 days) to transform to the stage of seed setting St-10 (Table 6). During this period, a flower remains open (St-3 to St-6) for $38 \mathrm{hrs}$ prior to stamen and petal senescence and for 277 hrs (St-7 to St-9) after the stamen and petal senescence (Figure 1). The anther dehiscence takes place during St-4 which last for about $10 \mathrm{hrs}$. Among the ten floral stages, St- 8 was found to be the longest followed by St-9. On the contrary, the St- 4 was found to be the shortest floral stage. The durations of St-2, St-3 and St-4 were similar.

Table 6. Floral transformations and floral processes of $A$. corniculatum

\begin{tabular}{|c|c|c|c|}
\hline $\begin{array}{l}\text { Floral } \\
\text { stage }\end{array}$ & $\begin{array}{l}\text { Range of life span (hrs) } \\
\text { (Avg. life } \pm \text { confidence } \\
\text { interval at } 95 \% \text { level) }\end{array}$ & Floral processes & $\begin{array}{l}\text { Pace of transformation after } \\
\text { completion of anthesis -taking St-2 } \\
\text { as zero }\end{array}$ \\
\hline St-1 & $23.8+5.08$ & Matured bud & \multirow{2}{*}{ Day 0} \\
\hline St-2 & $8.5 \pm 2.78$ & Duration of anthesis & \\
\hline St-3 & $11.7 \pm 3.43$ & $\begin{array}{l}\text { Duration prior to anther } \\
\text { dehiscence }\end{array}$ & Day1 \\
\hline St-4 & $9.4 \pm 2.52$ & $\begin{array}{l}\text { Anther dehiscence (pollen } \\
\text { presentation period) }\end{array}$ & Day 1 \\
\hline St-5 & $15.7 \pm 2.29$ & Drying of anthers & Day 2 \\
\hline St-6 & $39.9 \pm 8.30$ & Shrinkage of the petals & Day 4 \\
\hline St-7 & $17.0 \pm 3.60$ & $\begin{array}{l}\text { Senescence of petals and } \\
\text { stamens }\end{array}$ & Day 5 \\
\hline St-8 & $226.3 \pm 36.1$ & \multirow{2}{*}{ Predominantly female flower } & Day 13 \\
\hline St-9 & $174.7 \pm 25.59$ & & Day 21 \\
\hline
\end{tabular}

\subsection{Stigma Receptivity}

The stigma is surrounded by 5 anthers (Figure 1) and is wet type (Figure 2 A) due to the presence of stigmatic secretions reported during St-7, St-8 and St-9. 


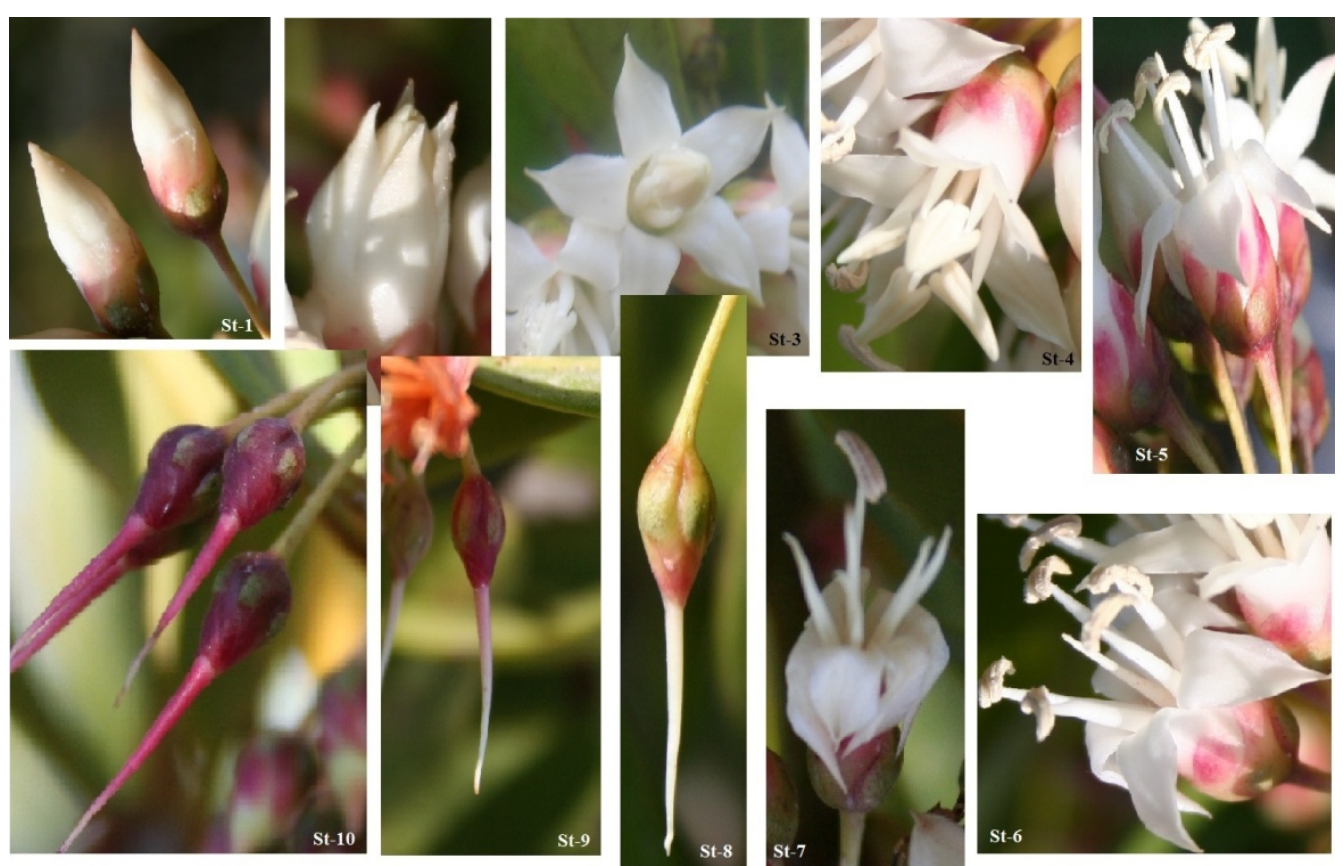

Figure 1. Floral transformation of $A$. corniculatum and the ten floral stages

Table 7. Percent Distribution of significant stigma receptivity, pollen grains of Category $\mathrm{Y}$ and $\mathrm{Z}$

\begin{tabular}{llllllll}
\hline \multirow{2}{*}{$\begin{array}{l}\text { Floral } \\
\text { Stage }\end{array}$} & $\begin{array}{l}\text { No. } \\
\text { samples }\end{array}$ & of & floral & \multicolumn{5}{l}{ Percent Distribution of } \\
\cline { 2 - 7 } & Group R & Group N & $\begin{array}{l}\text { Significant } \\
\text { receptivity (SR) }\end{array}$ & $\begin{array}{l}\text { stigma } \\
\text { grains } \\
\text { stigma }\end{array}$ & $\begin{array}{l}\text { Totalen } \\
\text { on }\end{array}$ & $\begin{array}{l}\text { Pollen } \\
\text { of Category Y }\end{array}$ & $\begin{array}{l}\text { Pollen grains } \\
\text { of Category Z }\end{array}$ \\
\hline St-1 & 100 & 0 & 0 & 0 & 0 & 0 \\
St-2 & 100 & 0 & 0 & 0 & 0 & 0 \\
St-3 & 100 & 0 & 0 & 0 & 0 & 0 \\
St-4 & 85 & 15 & 5.2 & 25 & 0 & 0 \\
St-5 & 73 & 27 & 9.40 & 25 & 0 & 0 \\
St-6 & 67 & 33 & 11.49 & 16 & 12 & 0 \\
St-7 & 33 & 67 & 23.34 & 14 & 34 & 2 \\
St-8 & 26 & 74 & 25.78 & 18 & 53 & 96 \\
St-9 & 32 & 68 & 23.69 & 3 & 1 & 2 \\
St-10 & 97 & 3 & 1.04 & 0 & 0 & 0 \\
\hline Total & 713 & 287 & 100 & 100 & 100 & 100 \\
\hline
\end{tabular}

\subsubsection{In Vitro Examination}

Significant stigma receptivity is present in seven floral stages i.e. St-4 to St-10 (Group R) and is absent in three floral stages St-1, St-2 and St-3 (Group-N). It increases from St-4 onwards and attains high values during St-7 to St-9 (with peak during St-8) and dramatically drops down in St-10. The maximum samples belonging to Group $\mathrm{R}$ were found in the floral stage St-7, St-8 and St-9 (Table 7). The percent occurrence of significant stigma receptivity rises sharply in St-7 (from 33\% to 67\%) and drops dramatically in St-10 (from 68\% to 3\%).

\subsubsection{In Vivo Examination}

Out of 200 specimens, 80 floral specimens had pollen grains and 120 floral specimens did not have pollen grain on their stigma. Further, of the ten floral stages, pollen grains have not been found on the stigma of St-1, St-2, 
St-3 and St-10. The percent distribution of pollen grains belonging to category Y and Z (Figure 2 B) have been juxtaposed against the percent distribution significant stigma receptivity over different floral stages (Table 7).

Pollen grains with enlarged germ pores (category Y) was seen St-6 onwards with peak in St-8. While pollen grains with germ tubes were seen maximum in St-8 (Table 7). The percent occurrence of significant stigma receptivity (in vitro method) and the percent occurrence of pollen with enlarged germ pores have been found to be strongly positively correlated $(r=0.71)$. The percent occurrence of significant stigma receptivity and the percent occurrence of pollen with pollen tubes have also been found to be positively correlated $(r=0.52)$. Hence, observations of the in vitro experiment are in conformity with those from the in vivo experiment. Maximum stigma receptivity is during St-8.

\subsubsection{Pollination Success}

Germinated pollen grains were absent in St-5 and St-6. Hence, the pollination success was zero during these floral stages. Out of the 20 floral specimens, only one floral specimen was found to have a pollen tube in St-7 and St-9 each. Therefore, the pollination success was found to be 0.1 in these floral stages. The pollination success ranged from 0.0 to 0.5 for stage St 8 . The average pollination success was found to be $0.01,0.15$ and 0.04 for St-7, St-8 and St-9 respectively.

\subsubsection{Diurnal Variation of Stigma Receptivity}

Stigma receptivity is high in the morning and evening hours and is unambiguously low- almost absent (found in $<5 \%$ flowers) during the afternoon (i.e. T-2). Thus, A. corniculatum has been found to show noticeable diurnal variation in the stigma receptivity. Although the number of flowers with significantly high stigma receptivity is very high in the morning and evening hours in all the four floral stages under examination, it is relative more in evening hours for St-6, St-7 and St-9 and is relatively more in morning hours in St-8.
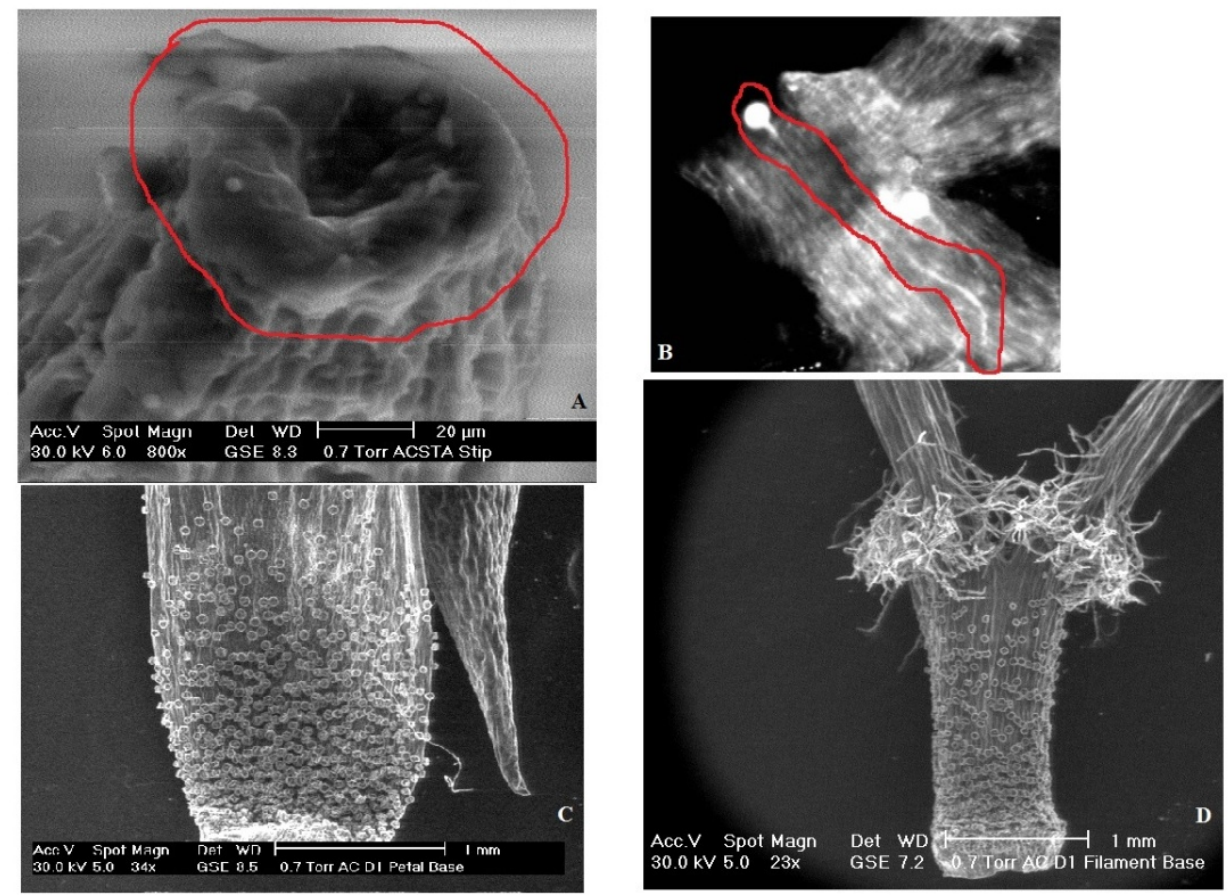

Figure 2. Stigmatic secretion during St-8 (A), Pollen germination and pollen tube growth through stylar canal in Sta-8 (B), Nectaries at base of petal (C) and Nectaries at base of stamen filament (D)

\subsection{Nectar Secretion}

\subsubsection{Floral Nectaries}

The floral nectaries, present at the base of the petals (Figure 2 C) and stamen filaments (Figure 2 D), are multicellular and stalked. These nectaries have two major parts i.e. basal stalk and apical head. The stalk is multicellular and composed of 1-5 layers of cells while the head is comprised of single layered 5-10 secretory 
cells covered with cuticle at apex.

\subsubsection{Availability of Nectar in Different Floral Stages}

The presence of nectaries is more at the base of the petal than the stamen filament. The nectar is found in four floral stages St- 4 to St-7; and is absent in the rest floral stages i.e. St-1 to St-3 and from St- 8 onwards (due to senescence of petals and androecium).

\subsubsection{Diurnal Variation in Nectar Availability}

The nectar availability is high during morning and evening hrs while very low during the noon period (Table 8). Considering all the 120 flowers, which were examined for nectar availability, the total quantum of nectar was $362.7 \mathrm{~mm}^{3}$. Out of this, the contribution of St-4, St-5, St-6 and St-7 was $104.1 \mathrm{~mm}^{3}, 62.6 \mathrm{~mm}^{3}, 98.7 \mathrm{~mm}^{3}$ and $97.3 \mathrm{~mm}^{3}$ respectively. During afternoon, the nectar availability per flower was found to decrease. The low availability of nectar during the afternoon may be partially attributed to the possibility of loss of nectar due to evaporation. However, the trichomes/corona present at the base of the filament (Figure $2 \mathrm{D}$ ) of the anther protect the nectar-to some extent- from getting evaporated. Therefore, there are only small possibilities of nectar getting evaporated during the afternoon period. It is more likely that the nectar productivity is reduced during the afternoon hours.

Table 8. Nectar availability $\left(\mathrm{mm}^{3}\right)$ in the various floral stages during different time periods

\begin{tabular}{lllllllllllll}
\hline \multirow{2}{*}{ Sr. No. /Floral age } & \multicolumn{3}{c}{ Morning (T1) } & \multicolumn{4}{c}{ Afternoon (T2) } & \multicolumn{7}{c}{ Evening (T3) } \\
& St-4 & St-5 & St-6 & St-7 & St-4 & St-5 & St-6 & St-7 & St-4 & St-5 & St-6 & St-7 \\
\hline 1 & 4.2 & 3.1 & 6.0 & 3.1 & 1.3 & 0.0 & 1.3 & 0.0 & 6.3 & 3.1 & 1.4 & 7.4 \\
2 & 3.1 & 1.9 & 5.3 & 3.1 & 0.0 & 2.5 & 2.8 & 0.0 & 6 & 2.8 & 3.1 & 7.5 \\
3 & 3.5 & 2.8 & 5.7 & 3.5 & 0.0 & 0.0 & 0.0 & 4.9 & 6.4 & 3.5 & 4.1 & 6.1 \\
4 & 3.4 & 1.8 & 5.9 & 3.5 & 0.0 & 0.0 & 0.0 & 4.2 & 4.6 & 3.1 & 3.9 & 4.1 \\
5 & 3.1 & 2.8 & 6.0 & 2.8 & 0.0 & 0.0 & 0.0 & 0.0 & 6.2 & 3.8 & 5.0 & 2.5 \\
6 & 2.8 & 3.8 & 6.2 & 2.5 & 1.5 & 0.0 & 0.0 & 0.0 & 5.4 & 3.0 & 3.5 & 4.3 \\
7 & 3.1 & 3.3 & 6.0 & 3.1 & 0.0 & 0.9 & 0.9 & 0.0 & 7.6 & 3.1 & 3.5 & 6.0 \\
8 & 3.5 & 1.9 & 5.7 & 3.1 & 0.0 & 1.2 & 1.1 & 9.2 & 4.1 & 3.1 & 2.8 & 3.8 \\
9 & 3.5 & 1.3 & 6.0 & 3.1 & 2.8 & 0.0 & 0.9 & 0.0 & 6.2 & 3.1 & 4.1 & 3.8 \\
10 & 3.1 & 1.7 & 5.3 & 3.1 & 1.0 & 0.0 & 0.0 & 0.0 & 6.8 & 4.6 & 2.5 & 2.5 \\
\hline
\end{tabular}

In the late evenings, the nectar availability was again high in all the ten specimens of the four floral stages. Interestingly, the nectar availability per flower in the evening hours was found to be slightly higher in St-4 than that of St-5, St-6 and St-7. It may be attributed to the fact that the flower of A. corniculatum is white which turns dull white or brown during St-6 and St-7. Further, the nocturnal visitors would be attracted by the bright white flowers of St-4 and not by the dull brown flowers of St-6 and St-7. Therefore, to attract the nocturnal floral visitors, the nectar availability per flower might possibly be higher in St-4 as compared to St-5, St-6 and St-7 during the evening hours. Considering the nectar availability per flower, it was found to be the maximum at St-4 (29\%) followed by St-6 and St-7 (27\% each) and St-5 (17\%).

\subsubsection{Chemical Composition of Nectar}

The floral nectar shows the presence of four sugars viz. fructose, galactose, maltose and sucrose and two amino acids viz. amino butyric acid and aspartic acid.

\subsection{Morphometry}

Considering St-1 as the benchmark (Table 9), the growth of the stamen is relatively more during early stage (St-1 to St-3) while that of pistil during latter stages (after St-3) is a morphological manifestation of protandry. 
Table 9. Dimensional details $(\mathrm{mm})$ of stamen and pistil at four floral stages

\begin{tabular}{|c|c|c|c|c|c|c|c|c|c|c|c|c|}
\hline \multirow{4}{*}{$\begin{array}{l}\text { Floral } \\
\text { stages }\end{array}$} & \multicolumn{7}{|l|}{ Stamen } & \multicolumn{5}{|c|}{ Pistil } \\
\hline & \multirow{2}{*}{\multicolumn{2}{|c|}{ Filament }} & \multicolumn{5}{|l|}{ Anther } & \multirow{2}{*}{\multicolumn{3}{|c|}{ Ovary }} & \multirow{2}{*}{\multicolumn{2}{|c|}{ Style }} \\
\hline & & & \multicolumn{2}{|l|}{ Length } & \multicolumn{3}{|c|}{ Width } & & & & & \\
\hline & Range & $\begin{array}{l}\text { Mean } \pm \\
\text { SD }\end{array}$ & Range & $\begin{array}{l}\text { Mean } \pm \\
\text { SD }\end{array}$ & Rang & & $\begin{array}{l}\text { Mean } \pm \\
\text { SD }\end{array}$ & Ran & & $\begin{array}{l}\text { Mean } \pm \\
\text { SD }\end{array}$ & Range & $\begin{array}{l}\text { Mean } \pm \\
\text { SD }\end{array}$ \\
\hline St-1 & 4 to 8 & $\begin{array}{l}6.7 \pm \\
0.9\end{array}$ & 4 to 5 & $\begin{array}{l}4.3 \pm \\
0.4\end{array}$ & $\begin{array}{l}1.5 \\
3.5\end{array}$ & to & $\begin{array}{l}2.0 \pm \\
0.3\end{array}$ & $\begin{array}{l}0.8 \\
1.5\end{array}$ & to & $\begin{array}{l}1.0 \pm \\
0.1\end{array}$ & $\begin{array}{ll}8.1 & \text { to } \\
10.0 & \end{array}$ & $\begin{array}{l}9.0 \pm \\
1.0\end{array}$ \\
\hline St-3 & 8 to 12 & $\begin{array}{l}10.1 \pm \\
1.2\end{array}$ & 4 to 5 & $\begin{array}{l}4.4 \pm \\
0.4\end{array}$ & $\begin{array}{l}1.2 \\
2.0\end{array}$ & to & $\begin{array}{l}1.9 \pm \\
0.2\end{array}$ & $\begin{array}{l}1.0 \\
1.5\end{array}$ & to & $\begin{array}{l}1.10 \pm \\
0.1\end{array}$ & $\begin{array}{ll}8.0 & \text { to } \\
11.0 & \end{array}$ & $\begin{array}{l}9.5 \pm \\
1.0\end{array}$ \\
\hline St-4 & $\begin{array}{ll}9 & \text { to } \\
12.5 & \end{array}$ & $\begin{array}{l}10.6 \pm \\
1.0\end{array}$ & 3.5 to 5 & $\begin{array}{l}4.2 \pm \\
0.4\end{array}$ & $\begin{array}{l}1.0 \\
2.0\end{array}$ & to & $\begin{array}{l}1.6 \pm \\
0.4\end{array}$ & $\begin{array}{l}1.0 \\
1.2\end{array}$ & to & $\begin{array}{l}1.0 \pm \\
0.1\end{array}$ & $\begin{array}{ll}9.0 & \text { to } \\
12.0 & \end{array}$ & $\begin{array}{l}10.6 \pm \\
0.9\end{array}$ \\
\hline St- 8 & 11 to 14 & $\begin{array}{l}12.1 \pm \\
0.8\end{array}$ & $\begin{array}{l}3.0 \text { to } \\
4.0\end{array}$ & $\begin{array}{l}3.2 \pm \\
0.4\end{array}$ & $\begin{array}{l}1.0 \\
1.1\end{array}$ & to & $\begin{array}{l}1.0 \pm \\
0.03\end{array}$ & $\begin{array}{l}1.0 \\
2.0\end{array}$ & to & $\begin{array}{l}1.3 \pm \\
0.4\end{array}$ & $\begin{array}{l}10.5 \text { to } \\
13.0\end{array}$ & $\begin{array}{l}11.7 \pm \\
0.7\end{array}$ \\
\hline
\end{tabular}

SD: Standard deviation.

\subsection{Pollination Biology}

\subsubsection{Foraging Behavior}

Birds were seen throughout day with more frequency during late evenings and early morning hrs. Though single individuals were reported, they generally found foraging in groups of 2 to 4 individuals per tree. They visit 4-12 inflorescences per tree in a landing. Further, they also visit the neighboring conspecific trees in one landing. Their foraging duration ranges from 0.05 minutes to 8 minutes with an average of 1.8 minute per inflorescence. All bird species prefer the inner branches. Many times they were found collecting ants as well. Ants are maximum reported foraging on flowers in early morning hrs. They forage in groups of 2 to 5 individual per flower. Ants always search for the nectar and never collect pollen. However, in the process to reach the nectar, they pass through anther and/or stigma (Table 10). Its foraging duration ranges from 0.01 to 10.0 minutes. They prefer to forage on floral stages after St-4 (when nectar secretion initiates). Once ants have entered in the flower, they do not allow any other species (such as bees) to forage on the same flower, even if the later have landed prior. Bees were seen throughout the day. They also forage in groups but they do not disturb other species. Their foraging durations range from 0.01 to 20 minutes with an average of 2 minutes per landing. Once landed on an inflorescence and remained undisturbed, they forage on almost every individual of the inflorescence, irrespective of the floral stage. During initial floral stages, they collect pollen while in latter floral stages, they collect nectar (Table 10). Bumble bees were seen more during morning and noon period. However, only one to two individuals were seen during the sightings. Their foraging duration ranges from 4 seconds to 27 minutes. Per landing, bumble bees were reported to visit one to five inflorescences. While in a single sight, they were seen to visit one to 20 conspecific trees. They were reported to collect pollen as well as nectar (Table 10). Butterflies were found to forage for still shorter durations. They never found foraging in groups. One diurnal and four nocturnal moths were found foraging on A. corniculatum.

All the flying floral visitors use the refluxed petals as landing ground. Butterflies hold the corolla cup while collecting nectar. Bees and bumble bees land on petals while birds land on branches. Bees, were never reported sharing an inflorescence with birds. 
Table 10. Foraging behaviors of pollinators \& potential pollinators

\begin{tabular}{|c|c|c|c|c|c|c|c|c|c|}
\hline \multirow{3}{*}{$\begin{array}{l}\text { Species } \\
\text { symbol* }^{*}\end{array}$} & \multirow{3}{*}{ Observations } & \multicolumn{4}{|c|}{ Body parts touching } & \multicolumn{4}{|c|}{ Foraging activity } \\
\hline & & \multicolumn{2}{|c|}{ Anther } & \multicolumn{2}{|c|}{ Stigma } & \multicolumn{2}{|c|}{ Pollen collection } & \multicolumn{2}{|c|}{ Nectar collection } \\
\hline & & No. & $\%$ & No. & $\%$ & No. & $\%$ & No. & $\%$ \\
\hline \multirow{4}{*}{ Ant-A } & Yes & 274 & 83 & 12 & 4 & 0 & 0 & 332 & 100 \\
\hline & No & 52 & 16 & 320 & 96 & 332 & 100 & 0 & 0 \\
\hline & Unknown & 6 & 1.8 & 0 & 0 & 0 & 0 & 0 & 0 \\
\hline & Total & 332 & 100 & 332 & 100 & 332 & 100 & 332 & 100 \\
\hline \multirow{4}{*}{ Be1 } & Yes & 185 & 99 & 179 & 96 & 48 & 26 & 173 & 93 \\
\hline & No & 0 & 0 & 7 & 4 & 131 & 70 & 12 & 6 \\
\hline & Unknown & 1 & 1 & 0 & 0 & 7 & 4 & 1 & 1 \\
\hline & Total & 186 & 100 & 186 & 100 & 186 & 100 & 186 & 100 \\
\hline \multirow{4}{*}{$\mathrm{Be} 2$} & Yes & 178 & 98 & 132 & 73 & 5 & 3 & 181 & 100 \\
\hline & No & 0 & 0 & 46 & 25 & 176 & 97 & 0 & 0 \\
\hline & Unknown & 3 & 2 & 3 & 2 & 0 & 0 & 0 & 0 \\
\hline & Total & 181 & 100 & 181 & 100 & 181 & 100 & 181 & 100 \\
\hline \multirow{4}{*}{$\mathrm{Be} 3$} & Yes & 96 & 100 & 89 & 93 & 68 & 71 & 75 & 78 \\
\hline & No & 0 & 0 & 6 & 6 & 28 & 29 & 20 & 21 \\
\hline & Unknown & 0 & 0 & 1 & 1 & 0 & 0 & 1 & 1 \\
\hline & Total & 96 & 100 & 96 & 100 & 96 & 100 & 96 & 100 \\
\hline \multirow{4}{*}{ Bi1 } & Yes & 42 & 100 & 42 & 100 & 0 & 0 & 00 & 00 \\
\hline & No & 0 & 0 & 0 & 0 & 42 & 100 & 26 & 38 \\
\hline & Unknown & 0 & 0 & 0 & 0 & 0 & 0 & 116 & 62 \\
\hline & Total & 42 & 100 & 42 & 100 & 42 & 100 & 42 & 100 \\
\hline \multirow{4}{*}{$\mathrm{Bi} 2$} & Yes & 35 & 100 & 35 & 100 & 0 & 0 & 35 & 100 \\
\hline & No & 0 & 0 & 0 & 0 & 35 & 100 & 0 & 0 \\
\hline & Unknown & 0 & 0 & 0 & 0 & 0 & 0 & 0 & 0 \\
\hline & Total & 35 & 100 & 35 & 100 & 35 & 100 & 35 & 100 \\
\hline \multirow{4}{*}{$\mathrm{Bi} 3$} & Yes & 107 & 100 & 107 & 100 & 0 & 0 & 103 & 96 \\
\hline & No & 0 & 0 & 0 & 0 & 106 & 99 & 4 & 4 \\
\hline & Unknown & 0 & 0 & 0 & 0 & 1 & 1 & 0 & 0 \\
\hline & Total & 107 & 100 & 107 & 100 & 107 & 100 & 107 & 100 \\
\hline \multirow{4}{*}{ BB1 } & Yes & 50 & 100 & 50 & 100 & 0 & 0 & 50 & 100 \\
\hline & No & 0 & 0 & 0 & 0 & 50 & 100 & 0 & 0 \\
\hline & Unknown & 0 & 0 & 0 & 0 & 0 & 0 & 0 & 0 \\
\hline & Total & 50 & 100 & 50 & 100 & 50 & 100 & 50 & 100 \\
\hline \multirow{4}{*}{ BB2 } & Yes & 29 & 100 & 29 & 100 & 0 & 0 & 29 & 100 \\
\hline & No & 0 & 0 & 0 & 0 & 29 & 100 & 0 & 0 \\
\hline & Unknown & 0 & 0 & 0 & 0 & 0 & 0 & 0 & 0 \\
\hline & Total & 29 & 100 & 29 & 100 & 29 & 100 & 29 & 100 \\
\hline BB3 & Yes & 75 & 75 & 75 & 75 & 20 & 20 & 93 & 93 \\
\hline
\end{tabular}




\begin{tabular}{|c|c|c|c|c|c|c|c|c|c|}
\hline \multirow{6}{*}{$\begin{array}{l}\text { Species } \\
\text { symbol* }\end{array}$} & \multirow{3}{*}{ Observations } & \multicolumn{4}{|c|}{ Body parts touching } & \multicolumn{4}{|c|}{ Foraging activity } \\
\hline & & \multicolumn{2}{|c|}{ Anther } & \multicolumn{2}{|c|}{ Stigma } & \multicolumn{2}{|c|}{ Pollen collection } & \multicolumn{2}{|c|}{ Nectar collection } \\
\hline & & No. & $\%$ & No. & $\%$ & No. & $\%$ & No. & $\%$ \\
\hline & No & 8 & 8 & 8 & 8 & 80 & 80 & 7 & 7 \\
\hline & Unknown & 17 & 17 & 17 & 17 & 0 & 0 & 0 & 0 \\
\hline & Total & 100 & 100 & 100 & 100 & 100 & 100 & 100 & 100 \\
\hline \multirow{4}{*}{$\mathrm{Bu} 1$} & Yes & 29 & 100 & 29 & 100 & 0 & 0 & 29 & 100 \\
\hline & No & 0 & 0 & 0 & 0 & 29 & 100 & 0 & 0 \\
\hline & Unknown & 0 & 0 & 0 & 0 & 0 & 0 & 0 & 0 \\
\hline & Total & 29 & 100 & 29 & 100 & 29 & 100 & 29 & 100 \\
\hline \multirow{4}{*}{$\mathrm{Bu} 2$} & Yes & 18 & 100 & 18 & 100 & 18 & 100 & 18 & 100 \\
\hline & No & 0 & 0 & 0 & 0 & 0 & 0 & 0 & 0 \\
\hline & Unknown & 0 & 0 & 0 & 0 & 0 & 0 & 0 & 0 \\
\hline & Total & 18 & 100 & 18 & 100 & 18 & 100 & 18 & 100 \\
\hline \multirow{4}{*}{$\mathrm{Bu} 3$} & Yes & 27 & 73 & 12 & 32 & 0 & 0 & 37 & 100 \\
\hline & No & 6 & 16 & 21 & 57 & 37 & 100 & 0 & 0 \\
\hline & Unknown & 4 & 11 & 4 & 11 & 0 & 0 & 0 & 0 \\
\hline & Total & 37 & 100 & 37 & 100 & 37 & 100 & 37 & 100 \\
\hline \multirow{4}{*}{$\mathrm{Bu} 4$} & Yes & 28 & 100 & 7 & 25 & 68 & 71 & 28 & 100 \\
\hline & No & 0 & 0 & 21 & 75 & 28 & 29 & 0 & 0 \\
\hline & Unknown & 0 & 0 & 0 & 0 & 0 & 0 & 0 & 0 \\
\hline & Total & 28 & 100 & 28 & 100 & 96 & 100 & 28 & 100 \\
\hline \multirow{4}{*}{$\mathrm{Bu} 5$} & Yes & 28 & 100 & 18 & 64 & 0 & 0 & 28 & 100 \\
\hline & No & 0 & 0 & 10 & 36 & 28 & 100 & 0 & 0 \\
\hline & Unknown & 0 & 0 & 0 & 0 & 0 & 0 & 0 & 0 \\
\hline & Total & 28 & 100 & 28 & 100 & 28 & 100 & 28 & 100 \\
\hline
\end{tabular}

* refer Table 3 .

\subsubsection{Pollinator's Efficiency}

Of the 21 major pollinators (R. Pandey \& C. N. Pandey, 2013b), 13 were found pollinators and 8 potential pollinators. Three pollinators were most efficient, two moderately efficient and eight the least efficient (Table 11). The availability and efficiency of floral visitors are summarized at Table 11. Some pollinators and potential pollinators foraging on flowers of A. corniculatum could be photo-documented (Figure 3).

\subsection{Breeding Systems}

All the three breeding mechanisms were found in this species. The fertilization success of autogamy, geitonogamy and xenogamy was $27.14 \%, 26.15 \%$ and $23.11 \%$ respectively.

\subsection{Reproductive Strategy}

A single inflorescence has 8 to 24 individuals which develope asynchronously. Therefore, a single inflorescence may have all floral stages at the same time. The petals are white but they do not have any other colour or pattern which could work as additional guide for the visitors. However, the strong fragrance attracts floral visitors. Due to gregarious flowering, this odour gets diffused in the atmosphere and, therefore, it does not act as a very focused floral guide. Thus, it attracts the visitors to the tree rather a particular flower/inflorescence. After reaching the inflorescence, the visitors hover around it.

The pollen presentation period, St-4, is about $10 \mathrm{hrs}$ which is much prior to stigma receptivity which is the 
maximum during St-8 and St-9. Stigma is exposed beyond the senescence of stamens (St-7 to St-9) for $277 \mathrm{hrs}$. The species keeps a very long period of significant stigma receptivity to receive pollen grains from other flowers after the possibility of self-pollination is ruled out. At these stages, the flower tends to get pollen grains (Table 7) by elongating the style (Table 9) and better exposing the stigma to the pollinators who may be hovering around. Further, nectar secretion initiates during St-4 which attains its peak during St-6 (Table 8) and terminates during St-8. During St-4, the nectar produced is intended to attract pollinators who can take away pollen grains to other receptive flowers because the stigma receptivity in the same flower is extremely low during this stage. However, St-6 onwards, the nectar is meant for attracting pollinators who may bring pollen grains to its receptive stigma. Hence, the temporal pattern of nectar production, much beyond the period of anther dehiscence is also supportive of cross breeding. These facts strongly suggest species favours cross pollination with keeping small possibility of self-pollination.

Table 11. Efficiency of Pollinators

\begin{tabular}{lllll}
\hline Sr. No. & Species Symbol* & Range of pollen load on body & Average pollen load \pm SE & Category allotted \\
\hline 1 & A & 0 to 9 & $2.4 \pm 0.9$ & Least efficient \\
2 & Be1 & 3 to 123 & $60.3 \pm 12.6 \mathrm{SE}$ & most efficient \\
3 & Be2 & 1 to 200 & $36 \pm 13.4 \mathrm{SE}$ & moderately efficient \\
4 & Be3 & 1 to 435 & $86.6 \pm 43.6$ & most efficient \\
5 & Bi1 & NA & NA & Potential pollinators \\
6 & Bi2 & NA & NA & Potential pollinators \\
7 & Bi3 & NA & NA & Potential pollinators \\
8 & BB1 & 3 to 52 & $61.7 \pm 20.6$ & moderately efficient \\
9 & BB2 & 17 to 109 & $16.4 \pm 3.6$ & most efficient \\
10 & BB3 & 6 to 24 & NA & Least efficient \\
11 & Bu1 & NA & NA & Potential pollinators \\
12 & Bu2 & NA & NA & Potential pollinators \\
13 & Bu3 & NA & NA & Potential pollinators \\
14 & Bu4 & NA & NA & Potential pollinators \\
15 & Bu5 & NA & NA & Potential pollinators \\
16 & M1 & NA & NA & Potential pollinators \\
17 & M2 & NA & NA & Potential pollinators \\
18 & M3 & NA & NA & Potential pollinators \\
19 & M4 & NA & NA & Potential pollinators \\
20 & M5 & NA & 2 to 14 & Potential pollinators \\
21 & Mo & Least efficient \\
\hline
\end{tabular}

* refer Table 3, NA: Not applicable 

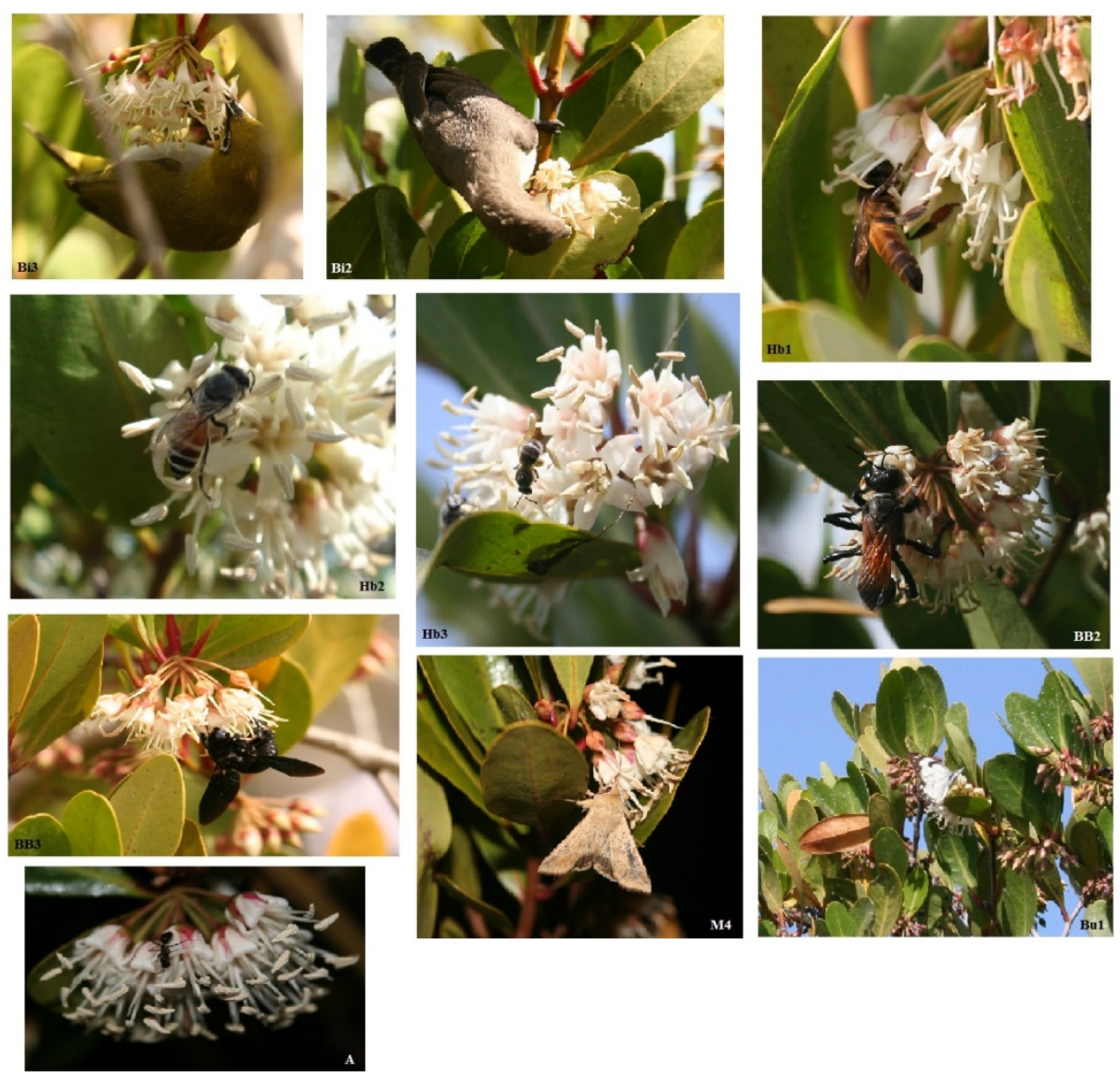

Figure 3. Pollinators and potential pollinators foraging on flowers of $A$. corniculatum

\section{Discussions and Conclusions}

\subsection{Floral Biology}

The range of individual per inflorescence was found 4-24 with an average of 16 per inflorescence which is in agreement with the findings (20 individuals) of Aluri (1990) indicating gregarious flowering in A. corniculatum. In A. marina, another mangrove species, individual floral life is 2-5 day while the inflorescence life may go up to 2-5 weeks (Clarke \& Myerscough, 1991). Aegiceras floridum takes 3 days (Almazol \& Cervancia, 2013) and $A$. corniculatum also take 2-3 days (Aluri, 1990) to complete flowering. However, in the present work $A$. corniculatum was found to complete the floral cycle in 21days on west coast of India. If drying and sencescence of petals are taken as indication of termination of floral life, it take 3-4 days by A. corniculatum in GOK. But, even if the the petals and stamens have gone, the stigma receptivity has not yet achieved its peak and mejority of flowers are yet to be pollinated (Table 7). Thus, the floral life does not complete with the sencence of petals and stamens. In fact, the flower remains open (St-3 to St-6) for $38 \mathrm{hrs}$ prior to stamen and petal senescence (effectively male flower) and for $277 \mathrm{hrs}$ (St-7 to St-9) after the stamen and petal senescence (effectively female flower).

Anthesis was reported during $0500 \mathrm{hrs}$ to $1900 \mathrm{hrs}$ with maximum completion during forenoon period for $A$. corniculatum (Aluri, 1900) while Almazol and Cervancia (2013) found anthesis initiation 0530 onwards with peak during 0900 to $1000 \mathrm{hrs}$ for A. floridum. Present work has reported anthesis throughout $24 \mathrm{hrs}$ with maximum peaks during early morning and midnight. Pollen and nectar have been found major floral rewards for many mangrove species (Aluri, 1990). Elliot et al. (1996) have reported 0.28 microliter/flower/day and 0.40 microliter/flower/day necter from A. germinans and L. racemosa respectively. Pollen grains are important floral rewards for A. corniculatum (Aluri, 1990). Present work has unambiguously found nectar and pollen both as floral reward of $A$. corniculam. During initial floral stages (till St-4) pollen are the floral reward as the nectar secretion has yet not started. However, nectar is the floral reward from St-4 to St-7. The significant variation in 
the nectar availability during morning, afternoon and evening hrs enfluences the frequency of pollinators and potential pollinators of $A$. Corniculatum, in MNP\&S.

Choudhury and Pandit (2001) have reported that the anther and stigma are at the same level. However, this study has found that during the later floral stages, the stigma elevates due to the elongation of the style. Choudhury and Pandit (2001) have also reported simultaneous maturation of anthers and stigma and treated it as a selfing species; however, any observational detail supporting simultaneous maturity of the anther and stigma has not been mentioned. The present research has unequivocally found that neither anther and stigma are at same level nor their maturation are not simultaneous. Aluri (1990) and Pandit and Choudhury (2001) have found A. corniculatum a predominantly selfing (autogamous) species. Present study has reported all the three breeding mechanisms in this species; however, the strong protandry reduces the possibility of autogamy to a significant level. Similar observations were made by Clarke and Myerscough (1991) for A. marina and reported protandry eliminates the possibility of self-pollination but asynchrony in flowering processes at inflorescence level and the visitation of pollinators favors geitonogamy which is found true for A. Corniculatum as well.

\subsection{Pollination Biology}

The pollination and reproductive biology of mangrove species are expected to differ among the populations. However, very few studies have addresed this aspect (Elliot, 1996; C. N. Pandey \& R. Pandey, 2010a). Pollinator dependent reproductive success has been reported in mangrove species (Elliot et al., 1996; C. N. Pandey \& R. Pandey, 2010a; Nadia et al., 2013). On the other hand, generalized pollination system is not uncommon for mangroves (Tomlinson et al., 1979; R. Pandey \& C. N. Pandey, 2013b). Laguncularia racemosa was reported to have the most specialized while Avicennia germinans with least specialized pollination (Nadia et al., 2013). Although known as wind pollinated species, insect pollination has been reported in R. mangle (Elliot, 1996; Sánchez-Núñez \& Mancera-Pineda, 2012) and R. mucronata (Pandey \& Pandey 2013c). Butterflies (A. germinans), wasp (L. racemosa) and birds were reported as major pollinators of Bahamas mangroves. Ge and Sun (1999) and Aluri (1990) found that A. corniculatum is predominantly pollinator-dependent for fruit setting. Similar observations were made for Kandelia caldel, another mangrove species (Sun et al., 1998). Nevertheless, the foraging pattern and asynchrony in the flowering processes within an inflorescence tend to geitonogamy in many mangrove species (Sun et al., 1998; Ge \& Sun, 1999) which is in conformity with the findings of present study.

The availability and efficiency of pollinators regulates the reproductive success of a pollinator dependent population. A total of 35 floral visitors of $A$. corniculatum have been documented by Pandit and Choudhury (2001). These 35 floral visitors included 7 nocturnal and 28 diurnal floral visitors. Further, 16 floral visitors belonged to the order Lepidoptera and the rest to Hymenoptera, Coleoptera, Diptera and Passeriformes (Pandit \& Choudhury, 2001). However, those floral visitors were neither categorized as pollinators/non pollinators/thieves/robber nor they were examined for their availability and pollination efficiency. On the other hand, Aluri (1990) reported Trigona sp. and Pseudapis oxybeloides collecting pollens from flowers of $A$. corniculatum which were not found in the present study. Almazol and Cervancia (2013) reported Xylocopa spp. and Apis dorsata foraging on A. floridum. Both of them are reported in the present work.

Pandit and Choudhury (2001) has reported that the members of Lepidoptera dominates among the floral visitors of A. corniculatum in Bhitarkanika mangrove forests which is also found in the present work. Three pollinators viz. Apis dorsata, Nectarinia zeylonica and Zosterops palpebrosus were reported in both the studies. Interestingly, Aluri (1990) has found Apis florae, Xylocopa latipes, X. pubescence, Nectarinia asiatica and N. zeylonia foraging on many mangroves on east coast (Andhra Pradesh) of India but A. corniculatum. However, present work has found Apis florae and as pollinator and N. zeylonia as potential pollinator of A. corniculatum. Further, Xylocarpa aestuans which was not reported by Aluri (1990) has been found as pollinator of $A$. corniculatum. Of the 35 floral visitors reported by Pandit and Choudhury (2001), 28 were not reported by Pandey and Pandey (2013b). On the other hand, of the 21 reported pollinators (including potential pollinators) of present work, 18 have not found by Pandit and Choudhury (2001) on east coast of India. Nevertheless, the floral visitors/pollinators of $A$. corniculatum reported in two mangrove forests viz. the Gulf of Kachchh (west coast of India) and Bhitarkanika (East coast of India) were found to be considerably different. Pollinator resource of $A$. corniculatum shows significant spatial and temporal variations within Marine National Park and Sanctuary, GOK, Gujarat (R. Pandey \& C. N. Pandey, 2013b). Further, pollinator resource availability has been found to enfluence the overall reproductive success of mangroves and their further distribution (C. N. Pandey \& R. Pandey, 2010a). Hence, in situ conservation of this species required comprehensive understanding of pollinator resources. 
Table 12. Efficiency and availability of Pollinators at the three research sites

\begin{tabular}{|c|c|c|c|c|c|c|c|c|}
\hline \multirow{3}{*}{ Group } & \multirow{3}{*}{ Scientific Name/family } & \multirow{3}{*}{ Efficiency } & \multicolumn{6}{|c|}{ Relative Occurrence* } \\
\hline & & & $\mathrm{PP}$ & PT & $\mathrm{SN}$ & PP & PT & SN \\
\hline & & & \multicolumn{3}{|c|}{ Diurnal } & \multicolumn{3}{|c|}{ Nocturnal } \\
\hline \multirow{3}{*}{ Honey bees/bees } & Lasioglossum sp. & Most efficient & A & A & $\mathrm{C}$ & $\mathrm{R}$ & MFV & $\mathrm{R}$ \\
\hline & Apis dorsata & Most efficient & A & $\mathrm{R}$ & $\mathrm{C}$ & $\mathrm{R}$ & MFV & $\mathrm{R}$ \\
\hline & Apis florea & Moderately efficient & A & A & $\mathrm{C}$ & $\mathrm{R}$ & MFV & $\mathrm{R}$ \\
\hline \multirow{3}{*}{ Bumble bees } & Sphex umbrosu & Most efficient & $\mathrm{R}$ & $\mathrm{R}$ & $\mathrm{R}$ & MFV & $\mathrm{R}$ & MFV \\
\hline & Scolia aureipennis & Moderately efficient & $\mathrm{R}$ & $\mathrm{R}$ & $\mathrm{R}$ & MFV & $\mathrm{R}$ & MFV \\
\hline & Xylocopa aestuans & Least efficient & $\mathrm{R}$ & $\mathrm{R}$ & $\mathrm{R}$ & MFV & $\mathrm{R}$ & MFV \\
\hline Ants & Crematogaster brunnea contemta & Least efficient & $\mathrm{R}$ & $\mathrm{R}$ & $\mathrm{R}$ & A & $\mathrm{C}$ & $\mathrm{C}$ \\
\hline Mosquitoes & Diptera -mosquito & Least efficient & MFV & $\mathrm{R}$ & $\mathrm{R}$ & $\mathrm{R}$ & $\mathrm{C}$ & $\mathrm{C}$ \\
\hline \multirow{5}{*}{ Moths } & Achaea janata & Least efficient & MFV & MFV & MFV & $\mathrm{R}$ & $\mathrm{C}$ & $\mathrm{R}$ \\
\hline & Crocidolomia biotalis & Least efficient & MFV & MFV & MFV & $\mathrm{R}$ & $\mathrm{C}$ & $\mathrm{R}$ \\
\hline & Utethesia latrix & Least efficient & $\mathrm{R}$ & $\mathrm{C}$ & $\mathrm{R}$ & MFV & MFV & MFV \\
\hline & Helicoverpa armigera & Least efficient & MFV & MFV & MFV & $\mathrm{R}$ & $\mathrm{C}$ & $\mathrm{R}$ \\
\hline & Spodoptera litura & Least efficient & MFV & MFV & MFV & $\mathrm{R}$ & $\mathrm{C}$ & $\mathrm{R}$ \\
\hline \multirow{3}{*}{ Birds } & Reed warber & $\begin{array}{l}\text { Potential pollinators } \\
\text { (probably most efficient) }\end{array}$ & MFV & $\mathrm{R}$ & $\mathrm{R}$ & $\mathrm{R}$ & $\mathrm{R}$ & $\mathrm{R}$ \\
\hline & Nectarinia zeylonica & $\begin{array}{l}\text { Potential pollinators } \\
\text { (probably most efficient) }\end{array}$ & MFV & $\mathrm{R}$ & $\mathrm{R}$ & $\mathrm{R}$ & $\mathrm{R}$ & $\mathrm{R}$ \\
\hline & Zosterops palpebrosus & $\begin{array}{l}\text { Potential pollinators } \\
\text { (probably most efficient) }\end{array}$ & MFV & $\mathrm{R}$ & $\mathrm{R}$ & $\mathrm{R}$ & $\mathrm{R}$ & $\mathrm{R}$ \\
\hline \multirow{4}{*}{ Butterflies } & Anaphaeis aurota & Potential pollinators & MFV & $\mathrm{R}$ & $\mathrm{R}$ & MFV & MFV & MFV \\
\hline & Tirumala septemtrionis & Potential pollinators & MFV & $\mathrm{R}$ & $\mathrm{R}$ & MFV & MFV & MFV \\
\hline & Vanessa cardui & Potential pollinators & MFV & $\mathrm{R}$ & $\mathrm{R}$ & MFV & MFV & MFV \\
\hline & $\begin{array}{l}\text { Member of family- } \\
\text { Lichniidae and Pieridae }\end{array}$ & Potential pollinators & MFV & $\mathrm{R}$ & $\mathrm{R}$ & MFV & MFV & MFV \\
\hline
\end{tabular}

Where *Source R. Pandey \& C. N. Pandey (2013b), PT: Pirotan, PP: Patthapir, SN: Sanada, MFV: Minor Floral Visitor (less than 5\%), A: Abundant, C: Common, R: Rare.

\subsection{Reproductive Strategy}

It is concluded that the floral biology of A. corniculatum strongly favors cross breeding. However, the asynchrony in flowering processes in inflorescences increases the possibility of geitonogamy. The pollination efficiency of pollinators and their availability also influence the reproductive biology of the species. For long term in situ conservation of this species, the pollinator resource needs to be conserved.

\section{Acknowledgements}

We are thankful to the Ministry of Environment and Forests, Government of India for sponsoring the project titled "Study of Pollination Biology and Reproductive Ecology of Major Mangrove Species of Gujarat" and extending full support to the project which made it possible to carry out the entire research. We are thankful to the entire staff at GEER Foundation, Gandhinagar for extending help from time to time. We would like to thank Dr. Harshad Salvi, Mrs. Urvi Joshi, Ms. Anjali Sharma, Mr. Sandeep Munjpara, Mr. Sandeep Patel, Mr. Virag Vyas, Mr. Nilesh Patel, for helping in field observations and to Mr. Sunil Panchal for photo documentation. We also thank, Pusa Institute, New Delhi, and Dr. Ramesh, Indian Forest Services, for identification of Pollinators. 


\section{References}

Almazol, A. E., \& Cervancia, C. R. (2013). Floral biology and pollination of three mangrove species (Aegiceras floridum Roem, \& Schults, Schphiphora hydrophyllacea Gaertn. F. and Xylocarpus granatum Koen) in Pagbilao Mangrove Forests, Quezon Province, Pilippines. Journal of Nature Science, 12(1), 39-47.

Alonoso, A. T., \& Herrera, C. M. (2008). Site-specific features affect pollination success of a gynodioecious understory shrub in a gender-specific mode. Ecoscience, 15, 358-365. http://dx.doi.org/10.2980/15-3-3115

Aluri, R. J. (1990). Observations on the floral biology of certain mangroves. Proceedings of the Indian National Science Academy, Part B. Biological Sciences, 56(4), 367-374.

Azuma, H., Toyota, M., Asakawa, Y., Takaso, T., \& Tobe, H. (2002). Floral scent chemistry of mangrove plants, Journal of Plant Research , 115(1), 47-53. http://dx.doi.org/10.1007/s102650200007

Banerjee, L. K., Shashtri, A. R. K., \& Nayar, M. P. (1989). Mangrove in India- Identification Manual. Calcutta: Botanical Survey of India.

Banerjee, L. K., Rao, T. A., Sastry, R. K., \& Ghosh, D. (2002). Diversity of coastal plant communities in India. Kolkata: Botanical Survey of India.

Clarke, P. J., \& Myerscoug, P. J. (1991). Floral biology and reproductive phenology of Avicennia marina in South-eastern Australia. Australian Journal of Botany, 39(3), 283-93. http://dx.doi.org/10.1071/BT9910283

Clark, P. J. (1993). Dispersal of grey mangrove (Avicennia marina) propagules in southeastern Australia. Aquatic Botany, 45(2-3), 195-204. http://dx.doi.org/10.1016/0304-3770(93)90021-N

Clarke, P. J. (1995). The population dynamics of the mangrove Shrub Aegiceras corniculatum (Myrsinaceae): fecundity, dispersal, estiblisment and population structure. Proceedings of the Linnean Society of New South Wales, 115, 35-44.

Coupland, G. T., Paling, E. I., \& McGuinness, K. A. (2005). Vegetative and reproductive phenologies of four mangrove species from northern Australia. Australian Journal of Botany, 53(2), 109-117. http://dx.doi.org/10.1071/BT04066

Dafni, A. (1992). Pollination Ecology: A Practical Approach. New York: Oxford University Press.

Dafni, A., \& Maués, M. M. (1998). A rapid and simple method to determine stigma receptivity. Sexual Plant Reproduction, 2, 117-80.

Darwin, C. (1888). The different forms of flowers on plants of the same species. Facsimile edition, (1986). Chicago, IL, USA: University of Chicago Press.

Davey, J. E. (1975). Notes on the Mechanism of Pollen Release in Bruguiera gymnorrhiza. Journal of South Africa Botany, 41, 269-272.

Debnath, H. S. (2004). Mangroves of Andaman and Nicobar Islands: Taxonomy and Ecology (A community Profile). Bhisan Singh and Mahendra Pal Singh.

Duck, N. C., Bunt, J. S., \& Williams, W. T. (1984). Observations on the floral and vegetative phenologies of North-eastern Australian Mangroves. Australian Journal of Botany, 32, 87-99. http://dx.doi.org/10.1071/BT9840087

Duck, N. C. (2006). Australia's Mangroves- the authoritative guide to Australia's mangrove plants. University of Queensland, Brisbane.

Elliot, N. B., Edward, D. C., \& Godfrey, P. J. (1996). Proceedings of the sixth sympozium on the natural history of of the Bahamas. In A. S. Linda, M. M. Godfrey, D. R. Suchy \& N. G. Suchy (Eds.), Pub. Bahamian Field Station, Bahamas.

Ellison, A. M. (2008). Managing mangroves with benthic biodiversity in mind: moving beyond roving banditry. Journal of Sea Research, 59, 2-15. http://dx.doi.org/10.1016/j.seares.2007.05.003

Ge, X. J., \& Sun, M. (1999). Reproductive biology and genetic diversity of a crypto-viviparous mangrove Aegiceras corniculatum (Myrsinaceae) using allozyme and intersimple sequence repeat (ISSR) analysis. Molecular Ecology, 8, 2061-2069. http://dx.doi.org/10.1046/j.1365-294x.1999.00821.x

GEER. (2000). Mangroves of Gujarat, Gujarat Ecological Education and Research (GEER) Foundation, Gandhinagar.

Geng, Q., Lian, C., Goto, S., Tao, J., Kimura, M., Islam, M. S., \& Hogetsu, T. (2008). Mating system, pollen and 
propagule dispersal and spatial genetic structure in a high-density population of the mangrove tree Kandelia candel. Molecular Ecology, 17, 4724-4739. http://dx.doi.org/10.1111/j.1365-294X.2008.03948.x

Ghosh, A., Gupta, S., Maity, S., \& Das, S. (2008). Study of floral morphology of some Indian mangroves in relation to pollination. Research Journal of Botany, 3(1), 9-16. http://dx.doi.org/10.3923/rjb.2008.9.16

Ghosh, A., \& Chakraborti, P. (2011). Evaluation of some mangrove species on the nature of their reproduction along the coastal belt of the Indian Sunderbans. Journal of Threatened Taxa, 4(3), 2427-2435. http://dx.doi.org/10.11609/JoTT.o2416.2427-35

Goethe, J. W. V. (1790). Versuch, die Metamorphose der Pflanzen zu erklären, C.W. Ettinger, Gotha. Reprint (D. Kuhn, ed.), Verlag Chemie, Weinheim, 1984.

Harder, L. D., \& Barrett, S. C. H. (1996). Pollen dispersal and mating patterns in animal-pollinated plants. In D. G. Lloyd, S. C. H. Barrett (Eds.), Floral biology: studies on floral evolution in animal-pollinated plants. (pp. 140-190). New York, NY, USA: Chapman \& Hall.

Henschel, A. W. (1820). Von der Sexualität der Pflanzen., W.G. Korn, Breslau.

Homer, L. E. (2009). Population structure and distance of gene flow in Avicennia marina (Forsk.) Vierh. (Avicenniaceae) on a local/ regional scale in the Northern Rivers of New South Wales, Australia', PhD thesis, Southern Cross University, Lismore, NSW.

Johansen, D. A. (1940). Plant Microtechnique. New York: McGraw-Hill Book Company.

Juncosa, A. M., \& Tomlinson, P. G. (1987). Floral development in mangrove Rhizophoraceae. American Journal of Botany, 74(8), 1263-1279. http://dx.doi.org/10.2307/2444162

Kado, T., Fujimoto, A., Le, H. G., Tuan, M., Phan, N. H., Harada, K., \& Tachida, H. (2004). Genetic structure of natural populations of three mangrove species, Avicennia marina, Kandelia candel and Lumnitzera racemosa, in Vietnam revealed by maturase sequences of plastid DNA. Plant Species Biology, 19(2), 91-99. http://dx.doi.org/10.1111/j.1442-1984.2004.00107.x

Kamruzzaman, Md., Sharma, S., \& Hagihara, A. (2013). Vegetative and reproductive phenology of the mangrove Kandelia obovata. Plant Species Biology, 28, 118-129. http://dx.doi.org/10.1111/j.1442-1984.2012.00367.x

Kathiresan, K., \& Bingham, B. L. (2001). Biology of mangroves and mangrove ecosystems. Advances in Marine Biology, 40, 181-251. http://dx.doi.org/10.1016/S0065-2881(01)40003-4

Kölreuter, G. J. (1761-1766). Vorläufige Nachricht von einigen, das Geschlecht der Pflanzen betreffenden Versuchen.

Lakshimi, M., Rajalakshmi, S., Parani, M., Anuratha, C. S. I., \& Parida, A. (1997). Molecular phylogeny of mangroves I. Use of molecular markers in assessing the intraspecific genetic variability in the mangrove species Acanthus ilicifolius Linn. (Acanthaceae). Theory of Applied Genetics, 94, 1121-1127. http://dx.doi.org/10.1007/s001220050525

Lakshmi, M., Parani, M., \& Parida, A. (2002). Molecular phylogeny of mangroves IX, molecular marker assisted intra-specific variation and species relationships in the Indian mangrove tribe Rhizophoreae, Aquatic Botany, 74, 201-217. http://dx.doi.org/10.1016/S0304-3770(02)00105-5

Landry, C. L., \& Rathcke, B. J. (2007). Do inbreeding and relative male fitness explain the maintenance of androdioecy in white mangrove, Laguncularia racemosa (Combretaceae). New Phytologist, 176, 891-901. http://dx.doi.org/10.1111/j.1469-8137.2007.02228.x

Lieu, N. T. H., \& Hong, P. N. (2004). Some development stages of the reproductive organs of Aegiceras corniculatum (L.) Blanco naturally growing in the coastal area of Northern Vietnam, In P. N. Hong (Ed.), Mangrove ecosystem in the red river coastal zone, biodiversity, ecology, socio-economics, management and education (pp.175-182). Agricultural Publishing House.

Maguire, T. L., Saenger, P., Baverstock, P., \& Henry, R. (2000). Microsatellite analysis of genetic structure in the mangrove species Avicennia marina (Forsk.) Vierh. (Avicenniaceae). Molecular Ecology, 9, 1853-1862. http://dx.doi.org/10.1046/j.1365-294x.2000.01089.x

McGuinness, K. A. (1997). Dispersal, establishment and survival of Ceriops tagal propagules in a north Australian mangrove forest. Oecologia (Berlin), 109, 80-87. http://dx.doi.org/10.1007/s004420050061

Melville, F., \& Burchett, M. (2002). Genetic variation in Avicennia marina in three estuaries of Sydney, (Australia) and implications for rehabilitation and management. Marine Pollution Bulletin, 44(6), 469-479. 
http://dx.doi.org/10.1016/S0025-326X(01)00259-4

Meyer, D. E. (1953). Biographisches und Bibliographisches über Christian Konrad Sprengel. Willdenowia; Mitt. Bot. Gart. Mus. Berlin-Dahlem, 1, 118-125.

Morrisey, D. J., Swales, A., Dittmann, S., Morrison, M. A., Lovelock, C. E., \& Neard, C. M. (2010). Ecology and management of temperate mangroves. Oceanography and Marine Biology: An Annual Review, 48, 43-160. http://dx.doi.org/10.1201/EBK1439821169-c2

Nadia, T., De L., Menezes, De N. L., \& Machado, I. C. (2013), Floral traits and reproduction of Avicennia schaueriana Moldenke (Acanthaceae): a generalist pollination system in the Lamiales. Plant Species Biology, 28, 70-80. http://dx.doi.org/10.1111/j.1442-1984.2011.00361.x

Nagrajan, P., Pandiarajan, C., Krishnmoorthy, M., \& Sophia, P. (2008). Reproductive fitness and success in mangroves: implication on conservation in Proceedings of Taal 2007, The $12^{\text {th }}$ World Lake conference. In (Eds.) M. Sengupta \& R. Dalwani, (pp. 29-33).

Naskar, K. R. (2004). Manual of Indian Mangroves. Daya Publishing House, Delhi.

Noske, R. A. (1993). Bruguiera hainesii: another bird-pollinated mangrove? Biotropica, 25, 481-483. http://dx.doi.org/10.2307/2388873

Odum, W. E., McIvor, C. C., \& Smith, III, T. J. (1982). The ecology of the mangroves of south Florida: a contry profile. U.S. Fish and Wild1ife Service, Office of Biological Services, Washington, D.C. FWS/OBS-81/24.

Pandey, C. N., \& Pandey, R. (2009). Floristic diversity and natural recruitment of mangroves in selected habitats of South Gujarat, GEER Foundation, Gandhinagar.

Pandey, C. N., \& Pandey, R. (2010a). Study of pollination biology and reproductive ecology of three major mangrove species of Gujarat, GEER Foundation, Gandhinagar.

Pandey, R., Pandey, C. N., \& Jain, B. K. (2010b) Reproductive phenology of Rhizophora mucronata Lamk. (Rhizophoraceae) in Gulf of Kachch,, Gujarat, India. Phytomorphology, 60 (3\&4), 91-100.

Pandey, R., \& Pandey, C. N. (2013a). Reproductive phenology of Aegiceras corniculatum (L) Blanco- a mangrove species in the Gulf of Kachchh, Gujarat, India, International Journal of Botany and Research, 3, 19-28.

Pandey, R., \& Pandey, C. N. (2013b). Spatial and temporal variations in floral visitors of a mangrove species Aegiceras corniculatum (L.) Blanco - in the Marine National Park, Gujarat, India. International Journal of Botany and Research, 3,35-42.

Pandey, R., \& Pandey, C. N. (2013c). Floral biology and pollination ecology of Rhizophora mucronata Lamk. in Gulf of Kachch,, Gujarat, India. International Journal of Botany and Research (in press).

Pandit, S., \& Choudhury, B. C. (2001). Factors affecting pollinator visitation and reproductive success in Sonneratia alba and Aaegiceras corniculatum in a mangrove forest in India. Journal of Tropical Ecoogy, 17, 431-447. http://dx.doi.org/10.1017/S0266467401001584

Rajgopalan, M. S. (1987). Mangroves as component of coastal ecosystem of Andaman's. In: Proc. Symp. Manag. Coastal Ecosystem and Oceanic resources of Andamans. Andaman Sci. Asso. Port Blair. 1-7.

Richards, A. J. (1997). Plant breeding systems. New York, NY, USA: Chapman \& Hall.

Sánchez-Núñez, D. A., \& Mancera-Pineda, J. E. (2011). Flowering patterns in three neotropical mangrove species: Evidence from a Caribbean island. Aquatic Botany, 94(4), 177-18. http://dx.doi.org/10.1016/j.aquabot.2011.02.005

Seetharaman, K., \& Kathiresan, K. (2011). Reproductive biology of a natural mangrove hybrid Rhizophora annamalayana and its parent species (R. apiculata and R. mucronata) (Rhizophoraceae), Botanica Marina, 54(6), 583-589. http://dx.doi.org/10.1515/BOT.2011.062

Solomon Raju, A. J., Jonathan, K. H., \& Vijaya Lakshmi, A. (2006). Pollination biology of Ceriops decandra (Griff.) Ding Hou (Rhizophoraceae)- an important true viviparous mangrove species. Current Science, 91(9), 1235-1238.

Solomon Raju, A. J., \& Karyamserry, H. J. (2008). Reproductive ecology of mangrove trees Ceriops decandra (Griff.) Ding Hou and Ceriops tagal (Perr.) C. B. Robinson (Rhizophoraceae). Acta Botanica Croatica., 67(2), 201-208. 
Solomon Raju, A. J., Rao, P. V., Kumar, S. R., \& Mohan, S. R. (2012). Pollination biology of the crypto-viviparous Avicennia species (Avicenniaceae). Journal of Threatened Taxa, 4(15), 3377-3389. http://dx.doi.org/10.11609/JoTT.o2919.3377-89

Sprengel, C. K. (1793). Das entdeckte Geheimniss der Natur im Bau und in der Befruchtung der Blumen I. Vieweg sen., Berlin Reprint by J. Cramer, H. K. Swann, Lehre, Weldon \& Wesley, Codicote, New York. http://dx.doi.org/10.5962/bhl.title.50179

Steinke, T. D. (1986). A preliminary study of buoyancy behaviour in Avicennia marina propagules. South African Journal of Botany, 52, 559-565.

Steinke, T. D. (1988). Vegetative and floral phenology of three mangroves in Mgeni Estuary. South African Journal of Botany, 54, 97-102.

Stocken, T., Van der, De Ryck, D. J. R., Balke, T., Bouma, T. J., Dahdouh-Guebas, F., \& Koedam, N. (2013). The role of wind in hydrochorous mangrove propagule dispersal. Biogeosciences Discuss., 10, 895-925. http://dx.doi.org/10.5194/bgd-10-895-2013

Sun, M., Wong, K. C., \& Lee, J. S. Y. (1998). Reproductive biology and population genetic structure of Kandelia candel (Rhizophoraceae), a viviparous mangrove species. American Journal of Botany, 85, 1631-1637. http://dx.doi.org/10.2307/2446492

Tomlinson, P. B. (1986). The botany of mangroves. New York: Cambridge University Press.

Tomlinson, P. B., Primack, R. B., \& Bunt, J. S. (1979). Preliminary observations on the floral biology in mangrove Rhizophoraceae. Biotropica, 11, 256-277. http://dx.doi.org/10.2307/2387918

Vogel, S. (1996). Christian Konrad Sprengel's theory of the flower: the cradle of flower ecology. In G. L. David \& C. H. Spencer (Eds.), Floral biology: studies on floral evolution in animal pollinated plants (pp. 44-62). Florence: International Thomson Publishing.

Willdenow, C. L. (1802). Grundriss der Kräuterkunde, zu Vorlesungen entworfen (3rd ed.) Haude \& Spener, Berlin.

Willson, M. F. (1983). Plant reproductive ecology. New York, NY, USA: John Wiley and Sons. http://dx.doi.org/10.1007/BF00047100

Wyatt, R. (1983). Pollinator-plant interactions and the evolution of breeding systems. In L. Real (Ed.) Pollination biology (pp. 51-95). Orlando, FL, USA: Academic Press.

Yamashiro, M. (1961). Ecological study on Kandelia candel (L.) Druce, with special reference to the structure and falling of the seedling. Hikobia, 2, 209-214.

\section{Copyrights}

Copyright for this article is retained by the author(s), with first publication rights granted to the journal.

This is an open-access article distributed under the terms and conditions of the Creative Commons Attribution license (http://creativecommons.org/licenses/by/3.0/). 